\title{
Physicochemical and Functional Properties of Flour and Protein Isolates from Two (2) Solojo Cowpea (Vigna Unguiculata L. Walp) Varieties in Nigeria
}

\author{
Olubamike Adetutu Adeyoju ${ }^{1}$, Kayode Oyebode Adebowale ${ }^{2}$, Bamidele Iromidayo Olu-Owolabi ${ }^{3}$, \\ Henry Okwudili Chibudike ${ }^{4}$, Eunice Chinedum Chibudike ${ }^{5}$ \\ ${ }^{1}$ Production, Analytical and Laboratory Management, Federal Institute of Industrial Research, Oshodi, Lagos, Nigeria \\ ${ }^{2}$ Department of Chemistry, Indistrial Unit, University of Ibadan, Ibadan, Nigeria \\ ${ }^{3}$ Department of Chemistry, Analytical Unit, University of Ibadan, Ibadan, Nigeria \\ ${ }^{4}$ Chemical, Fiber and Environmental Technology Department, Federal Institute of Industrial Research, Oshodi, Lagos, Nigeria \\ ${ }^{5}$ Planning, Technology Transfer and Information Management, Federal Institute of Industrial Research, Oshodi, Lagos, Nigeria \\ Email address: \\ henrychibudike@gmail.com (H. O. Chibudike)
}

\section{To cite this article:}

Olubamike Adetutu Adeyoju, Kayode Oyebode Adebowale, Bamidele Iromidayo Olu-Owolabi0, Henry Okwudili Chibudike, Eunice Chinedum Chibudike. Physicochemical and Functional Properties of Flour and Protein Isolates from Two (2) Solojo Cowpea (Vigna Unguiculata L. Walp) Varieties in Nigeria. World Journal of Food Science and Technology. Vol. 5, No. 2, 2021, pp. 25-32. doi: $10.11648 /$ j.wjfst.20210502.12

Received: April 27, 2021; Accepted: May 13, 2021; Published: June 4, 2021

\begin{abstract}
Protein isolates from dehulled defatted solojo cowpea seeds were prepared using isoelectric (CPIA) procedure. Two varieties of cowpea, Dark-Ash Solojo (DAS) and Brown Solojo (BS) were cleaned and divided into six portions. Both varieties of cowpea (DAS and BS) investigated were soaked in distilled water and germinated at varying periods i.e. 0, 6, 24, 36, 48 and 72hrs. Protein isolates were obtained from the treated and processed samples by isoelectric precipitation method which was subsequently followed by proximate and anti-nutritional analyses. Functional properties were also analysed which include Water Absorption Capacity (WAC) and Oil Absorption Capacity (OAC) of the protein isolates using standard methods. Amino acids and molecular weight of the protein isolates were determined by amino acid analyser and sodium-dodecyl-sulphate-polyacrylamide-gelelectrophoresis. Surface morphology, functional group and thermal properties were determined for protein isolates by scanning electron microscopy, Fourier Transform Infrared (FTIR) spectrometry and differential scanning calorimetry, respectively. Data were analysed using design expert software and Analysis of Variance (ANOVA) was carried out at $\alpha_{0.05}$. The moisture content, crude protein, crude fat, crude fibre and total ash of DAS ranged from 9.00-11.40, 24.82-31.00, 1.56-2.66, 1.43-1.67, and 3.20$4.14 \%$, respectively; while those of BS flours ranged from 7.10-9.50, 24.90-30.14, 1.17-2.37, 1.06-1.52 and 3.05-3.93\%, respectively. The protein contents for DAS were $81.57 \pm 0.53,86.44 \pm 0.84,89.39 \pm 1.51,90.23 \pm 0.53,91.81 \pm 0.77$ and $94.85 \pm 0.86$, while for BS were $84.39 \pm 0.39,85.44 \pm 0.56,90.05 \pm 0.10,90.47 \pm 0.89,92.78 \pm 0.28$ and $95.81 \pm 0.19 \%$ for $0,6,24,36,48$ and $72 \mathrm{hrs}$, respectively.
\end{abstract}

Keywords: Solojo Cowpea, Underutilised Legumes, Protein Isolate, Antinutrients Properties, DAS, BS

\section{Introduction}

The demand for protein has become so great and is still rapidly increasing due to world population explosion and growth of the food industry, cumulating in increasing demand for animal protein thereby putting pressure on the conventional animal sources. In the developing countries, animal protein such as meat, egg, fish and milk are out of the reach of many because of shortage in supply which has eventually led to increase in cost which makes adequate quantity consumption impossible [1, 2].

Consequently, it is undeniable that conventional animal protein sources are not adequate to meet with the demand, and on the long run unsustainable. It has therefore become imperative to look into new sources of protein to reduce the 
pressure on the existing sources [3-5].

According to modern nutrition recommendations, human beings ought to depend majorly on proteins of vegetable and legume origin for their dietary protein needs $[6,7]$. Pulses have been found to play very essential role in achieving the required nutritional recommendations, particularly in emerging and third world countries where the consumption of mammalian protein is low because of the high cost [8]. Apart from the high cost, large amounts of saturated fat and cholesterol are other problems associated with animal protein sources [9].

Concerns about high-cholesterol, has necessitated the recommendation of regular consumption of vegetable protein as opposed to animal protein by nutritionists. This has led to a renewed interest in legume protein because of their high level of protein which ranged between 20 and $60 \%$ [10]. They also have good protein quality in respect to their digestible and nutritional characters. Apart from this, the level of fibre in the body also increases with increased consumption of more plant food that helps in reducing the danger of bowel diseases, as well as cancer of the colon and prevalence of osteoporosis [11]. Compared to cereal grains, legume grains are also very excellent source of weight reduction fibers.

Several efforts by researchers have gone into methods of improving the functionality of protein by different modification methods. Physical modification of food proteins to enhance their capabilities, example, gel formation, adhesiveness, emulsification and foaming has been studied [12]. Instances of the physical modification of proteins include altering the preparation parameters such as temperature and $\mathrm{pH}$. This is done by bringing about partial denaturation of proteins using heat (dry or moist). Denaturation is believed to result in limited unraveling of the tightly crammed structure of the storage globulin proteins or in the regulated unravelling of the poly-peptides which brings about increased availability of sensitive areas of the molecules previously buried, thereby improving the protein functionality [13]. Physical modification using heating, freezing, or extrusion has also been carried out, and this has been found to denature protein structure causing reduced solubility and functionality [14]. Protein modification by high-pressure homogenization, causes insolubilization of proteins [15]. Other modifications that have been investigated include genetic modification [16] enzymatic modification and chemical modification [17].

Another modification method researcher has found is enzymatic modification, which is an uncomplicated and beneficial way to improve sensory and nutrition of plant proteins. Partial hydrolysis by enzymes has been found to improve the foam, gel and emulsification abilities of protein by enhancing its solvation [18]. Emulsification abilities is improved by exposing buried oil- loving groups, improving its surface hydrophobicity and decreasing its molecular mass; these improvements allow for better imbibition along water-oil border. The reason being that such enzymatic polymerization of proteins could be regulated to boost the functionality to the requested level for desired time [19]. Partial enzymatic hydrolysis has also been identified as somewhat easy and beneficial procedure for better palatability and nutritious value of plant proteins [20].

Enzymes, in particular, mammal and microbe transglutaminases also, have been harnessed to alter proteins range of capabilities [21], discovered that this modification considerably enhanced within a large spectrum of $\mathrm{pH}$, the emulsifying capacity and ability to form foam characteristics of the protein polymers of the two beans Cajanus cajan and Lablab purpureus were found to be better than the native protein [22]. As good as this is, it is very expensive.

Biochemical modification (Germination) as a means of improving functionality has not yet been fully exploited. This work therefore is designed to evaluate the ability of biochemical modification in enhancing the functional properties, and nutritive quality of Solojo protein. Solojo an underutilized legume commonly grown in the South-West region of Nigeria, will be biochemically modified for its possible industrial application through its functional properties.

\section{Experimental}

\subsection{Materials}

The raw material investigated in this research study is Solojo Cowpea (Vigna unguiculata L.) which occur in two varieties i.e. Dark-ash solojo (DAS) and Brown Solojo (BS). These two underutilized varieties found in South-West region of Nigeria where they are called 'Solojo' were obtained from Bodija market in Ibadan, Western Nigeria. They were stored in polyethylene bags at room temperature $\left(25-26^{\circ} \mathrm{C}\right)$.

\subsection{Methods}

The dehulled cowpea seeds were cleaned and screened to get rid of every irrelevant materials and unwholesome seeds. The Solojo seeds (DAS and BS) for germination were sterilized by soaking in $0.07 \%$ Sodium hypochlorite [23] for $30 \mathrm{~min}$, then rinsed thoroughly. The Solojo seeds were then immersed for $6 \mathrm{~h}$ in distilled water at ambient temperature $(1: 10 \mathrm{w} / \mathrm{v})\left(\sim 25^{\circ} \mathrm{C}\right)$, then placed in a colander and germinated under subdued light in an open laboratory [24] for 0, 6, 24, 36, 48 and $72 \mathrm{hrs}$. Other treated portions of the Solojo seeds (DAS and BS) were dehusked, dried, milled into flour and defatted. Protein was isolated by isoelectric precipitation method. Proximate, antinutritional analysis and functional properties [Water Absorption Capacity (WAC), Oil Absorption Capacity $(\mathrm{OAC})]$ of the flours and protein isolates were determined by standard methods. Amino acids and molecular weight of the protein isolates were determined by amino acid analyzer and sodium-dodecyl-sulphate-polyacrylamide-gel-electrophoresis. Surface morphology, functional group and thermal properties were determined for protein isolates by scanning electron microscopy, Fourier Transform Infrared (FTIR) spectrometry and differential scanning calorimetry, respectively. Data were analysed by descriptive statistics and ANOVA at $\alpha 0.05$. 


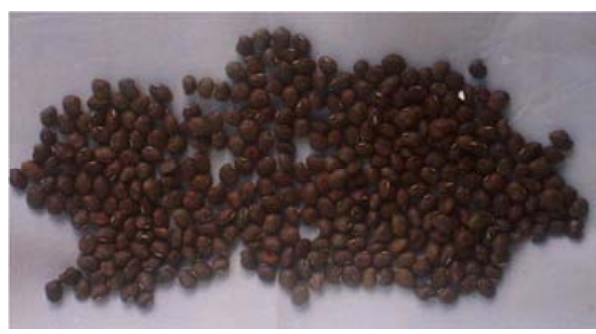

Figure 1. Dark- ash Solojo Cowpea.

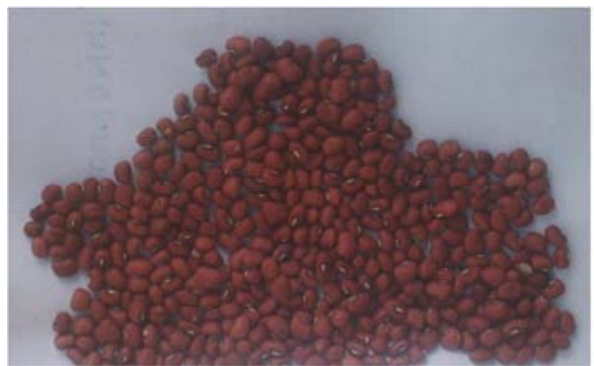

Figure 2. Brown Solojo Cowpea.

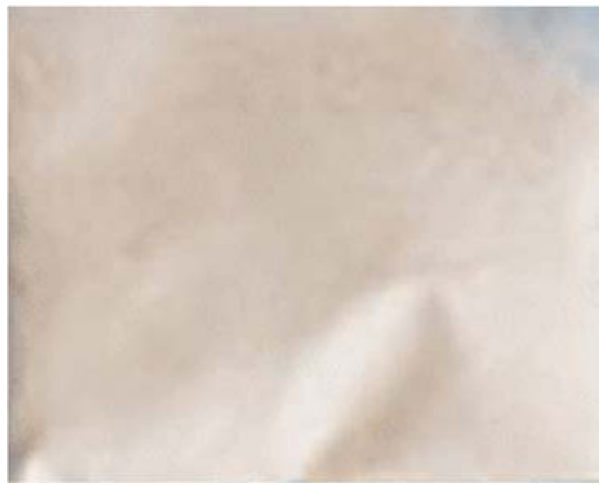

Figure 3. Pulverized Dark- ash Solojo Cowpea.

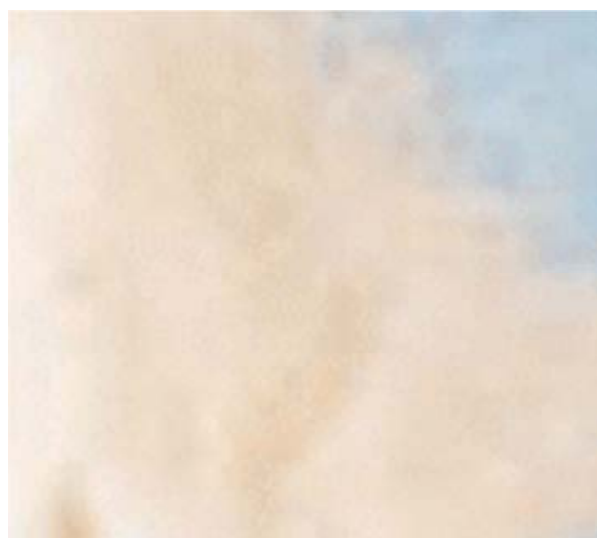

Figure 4. Pulverized Brown Solojo Cowpea.

\section{Result and Discussion}

Results of the proximate composition of the seed flour and the protein isolates are presented in Table 1. The whole (WCF) and dehulled defatted (DDCF) cowpea seed flour contained $22.30 \%-26.73 \%$ protein, $2.10 \%-2.30 \%$ fat, $4.10 \%$ $1.02 \%$ fibre, $3.77 \%-3.87 \%$ ash and $60 \%-59 \%$ carbohydrates respectively (on dry weight basis) as major components. The data obtained is comparable to that reported by Sosulski et al., [25].

Protein isolates (CPIA and CPIB) showed 75\% and 76\% protein content and a decrease in carbohydrate content from $59.78 \%$ to $13 \%$. The nutritional chemical analysis of both raw and germinated seed flours of full fat and defatted darkash and brown solojo cowpea. (FFDAS, FFBS, DFDAS and DFBS) varieties, as well as that for DAS and BS isolates are as shown in Tables 1, 2, 3, 4, 5 and 6 .

Table 1. Proximate composition analysis of FFDAS flour

\begin{tabular}{|c|c|c|c|c|c|c|}
\hline FFDAS & \% Moisture & $\%$ Protein & $\%$ fat & $\%$ Fibre & $\%$ Ash & NFE \\
\hline Raw & $11.40 \pm 1.44 \mathrm{a}$ & $24.82 \pm 2.80 \mathrm{c}$ & $2.66 \pm 0.08 \mathrm{a}$ & $1.67 \pm 0.03 \mathrm{c}$ & $4.14 \pm 0.42 \mathrm{ab}$ & $55.31 \pm 1.11 \mathrm{a}$ \\
\hline $6 \mathrm{~h}$ & $10.70 \pm 0.02 \mathrm{a}$ & $28.10 \pm 0.17 b$ & $2.16 \pm 0.02 b$ & $1.43 \pm 0.03 \mathrm{e}$ & $3.43 \pm 0.03 \mathrm{ab}$ & $54.18 \pm 0.03 b$ \\
\hline $24 \mathrm{~h}$ & $9.00 \pm 0.30 \mathrm{~b}$ & $30.40 \pm 0.02 \mathrm{a}$ & $1.37 \pm 0.56 \mathrm{c}$ & $1.87 \pm 0.03 \mathrm{a}$ & $3.37 \pm 0.02 \mathrm{ab}$ & $53.99 \pm 0.02 b c$ \\
\hline $36 \mathrm{~h}$ & $9.50 \pm 0.05 b$ & $30.50 \pm 0.03 a$ & $2.12 \pm 0.03 b$ & $1.59 \pm 0.02 \mathrm{~d}$ & $3.20 \pm 0.02 b$ & $53.09 \pm 0.03 \mathrm{~cd}$ \\
\hline $48 \mathrm{~h}$ & $9.50 \pm 0.03 b$ & $30.80 \pm 0.17 \mathrm{a}$ & $2.10 \pm 0.02 b$ & $1.59 \pm 0.03 \mathrm{~d}$ & $3.27 \pm 1.15 b$ & $52.74 \pm 0.02 \mathrm{~d}$ \\
\hline $72 \mathrm{~h}$ & $9.30 \pm 0.02 b$ & $31.00 \pm 0.03 \mathrm{a}$ & $1.87 \pm 0.03 \mathrm{~b}$ & $1.75 \pm 0.02 b$ & $3.61 \pm 0.02 \mathrm{ab}$ & $52.47 \pm 0.01 \mathrm{~d}$ \\
\hline
\end{tabular}

NFE- Nitrogen Free Extractive (Carbohydrate)

FFDAS- Full fat dark ask Solojo

Means in columns not followed by same alphabet (s) are significantly different at $5 \%$ level $(\mathrm{P}<0.05)$.

Table 2. Proximate composition analysis of DFDAS flour.

\begin{tabular}{|c|c|c|c|c|c|c|}
\hline DFDAS & $\%$ Moisture & $\%$ Protein & $\%$ Fat & $\%$ Fibre & $\%$ Ash & NFE \\
\hline Raw & $12.70 \pm 0.07^{\mathrm{a}}$ & $25.86 \pm 1.18^{\mathrm{e}}$ & $1.83 \pm 0.06^{\mathrm{a}}$ & $1.65 \pm 0.04^{\mathrm{b}}$ & $4.05 \pm 0.15^{\mathrm{a}}$ & $53.91 \pm 0.66^{\mathrm{b}}$ \\
\hline $6 \mathrm{~h}$ & $12.20 \pm 0.36^{\mathrm{ab}}$ & $28.95 \pm 0.07^{\mathrm{d}}$ & $1.06 \pm 0.03^{\mathrm{b}}$ & $1.36 \pm 0.02^{\mathrm{c}}$ & $2.89 \pm 0.01^{\mathrm{c}}$ & $53.54 \pm 0.05^{b}$ \\
\hline $24 \mathrm{~h}$ & $12.50 \pm 0.07^{\mathrm{ab}}$ & $31.45 \pm 0.04^{\mathrm{c}}$ & $0.32 \pm 0.02^{f}$ & $1.20 \pm 0.03^{\mathrm{d}}$ & $2.99 \pm 0.02^{\mathrm{c}}$ & $51.54 \pm 0.05^{\mathrm{c}}$ \\
\hline $36 \mathrm{~h}$ & $11.60 \pm 0.08^{\mathrm{bc}}$ & $33.69 \pm 0.05^{\mathrm{b}}$ & $0.73 \pm 0.05^{\mathrm{c}}$ & $1.35 \pm 0.02^{\mathrm{c}}$ & $2.92 \pm 0.02^{\mathrm{c}}$ & $49.71 \pm 0.02^{\mathrm{d}}$ \\
\hline $48 \mathrm{~h}$ & $12.30 \pm 1.18^{\mathrm{ab}}$ & $34.40 \pm 0.02^{\mathrm{ab}}$ & $0.41 \pm 0.02^{\mathrm{e}}$ & $1.33 \pm 0.04^{\mathrm{c}}$ & $3.44 \pm 0.02^{\mathrm{b}}$ & $48.12 \pm 0.03^{f}$ \\
\hline $72 \mathrm{~h}$ & $10.93 \pm 0.15^{\mathrm{c}}$ & $34.62 \pm 0.03^{\mathrm{a}}$ & $0.61 \pm 0.03^{\mathrm{d}}$ & $1.84 \pm 0.05^{\mathrm{a}}$ & $3.53 \pm 0.03^{b}$ & $48.47 \pm 0.26^{\mathrm{e}}$ \\
\hline
\end{tabular}

DFDAS- Defatted dark ash Solojo

NFE- Nitrogen Free Extractive

Means in columns not followed by same alphabet (s) are significantly different at $5 \%$ level $(\mathrm{P}<0.05)$. 


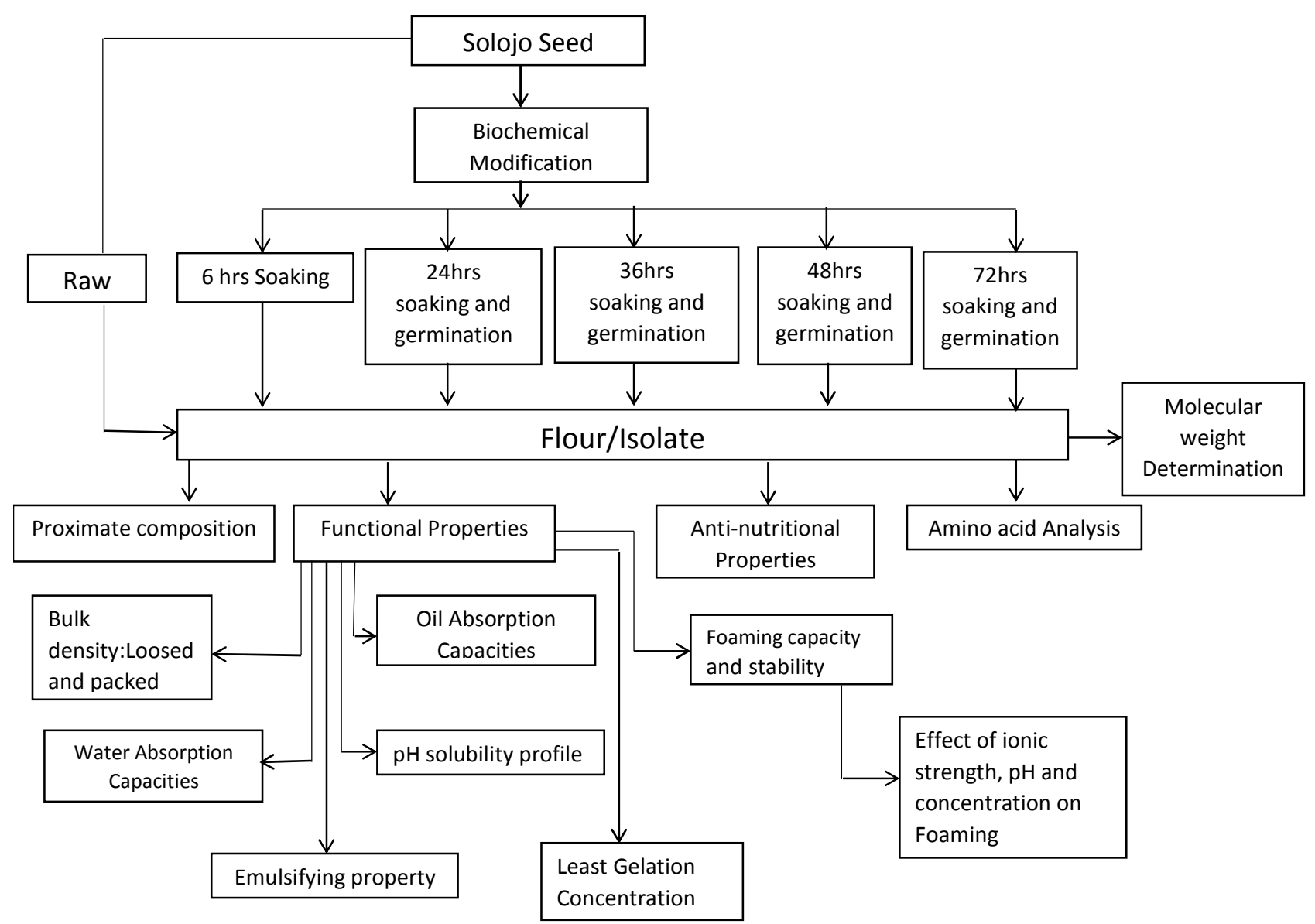

Figure 5. Schematic representation of treatment and analysis on sample flours and isolates carried out.

Determination of the quality of materials, overall acceptability of the product by consumers and nutritional value establishment are all hinged on proximate analysis of the product [26]. The nutritional chemical analysis of both raw and germinated seed flours of full fat and defatted dark-ash and brown solojo cowpea. (FFDAS, FFBS, DFDAS and DFBS) varieties, as well as that for DAS and BS isolates are as shown in Tables 1-6. Storage stabilit of any food is established by determining the moisture content directly or by ascertaining the dry matter quantity of the sample indirectly. Germination caused the moisture content to decrease with time from Raw (Control) to germinated beans, this observation has similarity to that expressed by Nahid, et al. [27] for Lima beans, where the amount of moisture ranged between 4 to $13 \%$. Ghavidel and Prakash also reported similar observation for lentil, cowpea and chickpea germinated seed flours with decrease in moisture content after removing the hulls

In 2001, Abdalla et al., [28] in his study, on chickpea flours, also observed an initial increase in moisture content with soaking which later reduced on germinating from $7.69 \%$ to $7.30 \%$. Moisture content reduced significantly $(\mathrm{p}<0.05)$ with germination. This might be as a result of utilisation of the water for metabolic processes initiated by soaking. On the contrary, observation of increase in moisture content of two varieties of tigernut with germination from 7.14 to $9.98 \%$ was made by Chinma et al., 2008 [29]. Likewise, D'souza, made similar observation of increase in moisture for field bean with germination, going from 5.23-11.35 after $60 \mathrm{~h}$ of germination, this was adduced to increased number of cells for hydration and low dry matter content.

Table 3. Proximate composition analysis of FFBS flour.

\begin{tabular}{|c|c|c|c|c|c|c|}
\hline FFBS & $\%$ Moisture & $\%$ Protein & $\%$ Fat & $\%$ Fibre & $\%$ Ash & NFE \\
\hline Raw & $9.50 \pm 0.30^{\mathrm{a}}$ & $24.90 \pm 0.06^{\mathrm{f}}$ & $2.37 \pm 0.08^{\mathrm{a}}$ & $1.52 \pm 0.08^{\mathrm{b}}$ & $3.93 \pm 0.03^{\mathrm{a}}$ & $57.78 \pm 0.03^{\mathrm{e}}$ \\
\hline $6 \mathrm{~h}$ & $8.10 \pm 0.10^{\mathrm{b}}$ & $26.43 \pm 0.22^{\mathrm{e}}$ & $1.65 \pm 0.04^{\mathrm{b}}$ & $1.43 \pm 0.04^{\mathrm{c}}$ & $3.24 \pm 0.03^{c}$ & $59.15 \pm 0.04^{\mathrm{a}}$ \\
\hline $24 \mathrm{~h}$ & $7.90 \pm 0.03^{\mathrm{bc}}$ & $26.99 \pm 0.05^{\mathrm{d}}$ & $1.42 \pm 0.03^{\mathrm{c}}$ & $1.21 \pm 0.02^{\mathrm{e}}$ & $3.05 \pm 0.06^{\mathrm{e}}$ & $58.92 \pm 0.03^{b}$ \\
\hline $36 \mathrm{~h}$ & $7.90 \pm 0.05^{\mathrm{bc}}$ & $27.80 \pm 0.04^{\mathrm{c}}$ & $1.36 \pm 0.03^{\mathrm{cd}}$ & $1.06 \pm 0.01^{\mathrm{f}}$ & $3.15 \pm 0.04^{\mathrm{d}}$ & $58.73 \pm 0.03^{c}$ \\
\hline $48 \mathrm{~h}$ & $7.80 \pm 0.01^{\mathrm{c}}$ & $28.20 \pm 0.04^{b}$ & $1.29 \pm 0.03^{\mathrm{e}}$ & $1.32 \pm 0.02^{\mathrm{d}}$ & $3.32 \pm 0.01^{\mathrm{b}}$ & $58.07 \pm 0.02^{\mathrm{d}}$ \\
\hline $72 \mathrm{~h}$ & $7.10 \pm 0.01^{\mathrm{d}}$ & $30.14 \pm 0.05$ & $1.17 \pm 0.08^{\mathrm{f}}$ & $2.15 \pm 0.05^{\mathrm{a}}$ & $3.24 \pm 0.02^{\mathrm{c}}$ & $56.20 \pm 0.03^{f}$ \\
\hline
\end{tabular}

NFE- Nitrogen Free Extractive (Carbohydrate)

FFBS- Full fat brown Solojo

Means in columns not followed by same alphabet (s) are significantly different at $5 \%$ level $(\mathrm{P}<0.05)$. 
Table 4. Proximate composition analysis of DFBS flour.

\begin{tabular}{|c|c|c|c|c|c|c|}
\hline DFBS & $\%$ Moisture & $\%$ Protein & $\%$ Fat & $\%$ Fibre & $\%$ Ash & NFE \\
\hline Raw & $12.20 \pm 0.56^{\mathrm{a}}$ & $25.64 \pm 0.15^{\mathrm{f}}$ & $1.89 \pm 0.10^{\mathrm{a}}$ & $1.37 \pm 0.09^{c}$ & $3.93 \pm 0.05^{\mathrm{a}}$ & $54.99 \pm 0.20^{\mathrm{d}}$ \\
\hline $6 \mathrm{~h}$ & $10.20 \pm 0.04^{b c}$ & $26.22 \pm 0.04^{\mathrm{e}}$ & $1.20 \pm 0.01^{\mathrm{c}}$ & $1.58 \pm 0.03^{\mathrm{a}}$ & $2.99 \pm 0.02^{\mathrm{e}}$ & $57.81 \pm 0.01^{\mathrm{a}}$ \\
\hline $24 \mathrm{~h}$ & $10.30 \pm 0.02^{\mathrm{b}}$ & $29.26 \pm 0.04^{\mathrm{d}}$ & $0.10 \pm 0.02^{\mathrm{f}}$ & $1.50 \pm 0.03^{\mathrm{b}}$ & $3.36 \pm 0.03^{\mathrm{c}}$ & $55.85 \pm 0.02^{b}$ \\
\hline $48 \mathrm{~h}$ & $9.80 \pm 0.01^{\mathrm{c}}$ & $29.92 \pm 0.04^{b}$ & $0.67 \pm 0.02^{\mathrm{d}}$ & $1.34 \pm 0.02^{\mathrm{cd}}$ & $3.30 \pm 0.03^{\mathrm{d}}$ & $55.39 \pm 0.03^{\mathrm{c}}$ \\
\hline $72 \mathrm{~h}$ & $10.00 \pm 0.02^{\mathrm{bc}}$ & $31.80 \pm 0.02^{\mathrm{a}}$ & $1.67 \pm 0.03^{\mathrm{b}}$ & $1.39 \pm 0.03^{\mathrm{c}}$ & $3.42 \pm 0.02^{\mathrm{b}}$ & $51.72 \pm 0.03^{\mathrm{e}}$ \\
\hline
\end{tabular}

DFBS- Defatted brown Solojo

NFE- Nitrogen Free Extractive

Means in columns not followed by same alphabet (s) are significantly different at $5 \%$ level $(\mathrm{P}<0.05)$.

Observation of moisture content range from $9.19 \%$ to $11.83 \%$ for five lima bean varieties was made by Yellavila et al., with 'Koloenu brown' having the least moisture content while 'Nsawam black and white' recorded uppermost moisture quantity. Moisture contents of the present study fall within the approved range for flours $(<14 \%)$. The defatted samples were also noticed to have larger moisture content than the full fat, as was also expressed by Rumiyati et al., [30]. In all, low moisture content of less than $14 \%$ is recommended for greater resistance to microbial growth, better storability and prevention of the development of hydrolytic rancidity.

The appreciable increase in protein quantity observed in sprouted Solojo Cowpea could be ascribed to increased formation of some amino acids from protein degradation during sprouting. Chinma et al., also observed a similar increase in protein content of sprouted brown tiger nut from 10.6-12.4\% after $48 \mathrm{~h}$ sprouting. In 2013, Myrene [31] deduced that significant increase in protein content could be ascribed to improved water activity as a result of activation of hydrolytic enzymes. It could also be due to hormonal changes, according to Nenogaki et al., or a component change resulting from the degradation of other constituents. While Kavitha and Parimalavalli [32] also surmised the increase could be as a result of formation of enzyme proteins.

Table 5. Proximate composition analysis of DAS protein isolate.

\begin{tabular}{|c|c|c|c|c|c|}
\hline DAS & \%Moisture & \%Protein & \%Ash & $\%$ Fat & NFE \\
\hline Raw & $10.60 \pm 0.64^{\mathrm{a}}$ & $81.57 \pm 0.53^{\mathrm{e}}$ & $2.52 \pm 0.22^{\mathrm{c}}$ & $2.43 \pm 0.23^{\mathrm{a}}$ & $2.93 \pm 0.05^{\mathrm{a}}$ \\
\hline $6 \mathrm{~h}$ & $3.25 \pm 0.15^{\mathrm{c}}$ & $89.39 \pm 1.51^{\mathrm{c}}$ & $3.79 \pm 0.29^{b}$ & $1.94 \pm 0.16^{\mathrm{b}}$ & $1.63 \pm 0.12^{\mathrm{de}}$ \\
\hline $24 \mathrm{~h}$ & $1.54 \pm 0.06^{\mathrm{d}}$ & $94.85 \pm 0.86^{\mathrm{a}}$ & $2.13 \pm 0.20^{\mathrm{d}}$ & $0.08 \pm 0.02^{\mathrm{c}}$ & $1.40 \pm 0.10^{\mathrm{e}}$ \\
\hline $36 \mathrm{~h}$ & $5.15 \pm 0.03^{b}$ & $91.81 \pm 0.77^{\mathrm{b}}$ & $0.73 \pm 0.03^{\mathrm{e}}$ & $0.25 \pm 0.01^{\mathrm{c}}$ & $2.07 \pm 0.02^{\mathrm{c}}$ \\
\hline $48 \mathrm{~h}$ & $4.80 \pm 0.20^{\mathrm{b}}$ & $86.44 \pm 0.84^{\mathrm{d}}$ & $5.92 \pm 0.22^{\mathrm{a}}$ & $0.23 \pm 0.02^{\mathrm{c}}$ & $2.62 \pm 0.32^{\mathrm{b}}$ \\
\hline $72 \mathrm{~h}$ & $5.14 \pm 0.11^{\mathrm{d}}$ & $90.23 \pm 0.53^{b c}$ & $2.53 \pm 0.08^{c}$ & $0.30 \pm 0.10^{\mathrm{c}}$ & $1.80 \pm 0.20^{\mathrm{cd}}$ \\
\hline
\end{tabular}

DAS- Dark -ash protein Isolate

NFE- Nitrogen free extractive

Means in columns not followed by same alphabet (s) are significantly different at $5 \%$ level $(\mathrm{P}<0.05)$.

Table 6. Proximate composition analysis of BS protein isolate.

\begin{tabular}{|c|c|c|c|c|c|}
\hline BS & \%Moisture & $\%$ Protein & \%Ash & \%Fat & NFE \\
\hline Raw & $9.40 \pm 0.20^{\mathrm{a}}$ & $84.39 \pm 0.39^{\mathrm{e}}$ & $3.74 \pm 0.05^{b}$ & $1.64 \pm 0.14^{\mathrm{a}}$ & $0.71 \pm 0.07^{\mathrm{f}}$ \\
\hline $6 \mathrm{~h}$ & $3.22 \pm 0.14^{\mathrm{d}}$ & $90.47 \pm 0.89^{c}$ & $4.80 \pm 0.40^{\mathrm{a}}$ & $0.27 \pm 0.03^{\mathrm{bc}}$ & $1.25 \pm 0.04^{\mathrm{d}}$ \\
\hline $24 \mathrm{~h}$ & $0.61 \pm 0.02^{\mathrm{e}}$ & $95.81 \pm 0.19^{\mathrm{a}}$ & $2.26 \pm 0.20^{\mathrm{d}}$ & $0.32 \pm 0.04^{\mathrm{b}}$ & $1.00 \pm 0.10^{\mathrm{e}}$ \\
\hline $48 \mathrm{~h}$ & $3.28 \pm 0.04^{\mathrm{d}}$ & $92.78 \pm 0.28^{b}$ & $1.90 \pm 0.30^{\mathrm{de}}$ & $0.18 \pm 0.02^{\mathrm{cd}}$ & $1.87 \pm 0.03^{\mathrm{c}}$ \\
\hline $72 \mathrm{~h}$ & $7.58 \pm 0.12^{\mathrm{b}}$ & $86.44 \pm 0.56^{\mathrm{d}}$ & $1.81 \pm 0.17^{\mathrm{e}}$ & $0.12 \pm 0.01^{\mathrm{d}}$ & $4.05 \pm 0.10^{\mathrm{a}}$ \\
\hline
\end{tabular}

BS- Brown protein Isolate

NFE- Nitrogen free extractive

Means in columns not followed by same alphabet (s) are significantly different at $5 \%$ level $(\mathrm{P}<0.05)$.

A comparable increase in protein content was also reported in Ugba (African oil bean), Mungbean; Field beans and Australian sweet lupin upon germination. In 2015, Devi et al., [33] also detected notable rise in crude protein after malting in all the three accerssions of cowpea they worked upon. This observed increase in protein quantity may, according to them, be associated with loss in dry matter, especially carbohydrates due to respiration during malting. Similarly, Zhang et al. [34], observed significant increase in protein content of buckwheat after germination for $72 \mathrm{~h}$, this is probably due to higher rate of protein synthesis compared to proteolysis. On the contrary, El-Adawy et al. [35], observed a reduction in protein content after germinating for $120 \mathrm{~h}$, mung bean, going from 26.40 to $22.52 \%$; Pea from 34.70 to $30.73 \%$; and lentil from 31.41 to $28.37 \%$. Murugkar et al., [36] alluded the rise in protein observed in the nutrient of their mixes to compensative increment in free amino acids and peptides. The amount of the crude protein of the full fat ranged between 24.82 and $31.00 \%$ for FFDAS and 24.90 to $30.14 \%$ for FFBS while that of DFDAS and DFBS was 
between 25.86 to $34.62 \%$, and 25.64 to $31.80 \%$ respectively. This is expected because the removal of oil due to defatting reduces the competition of the oil with protein in the flour during analysis. The protein content of the isolates too was observed to increase with germination. The NFE of the FFDAS was also found to be higher than that of DFDAS; this was due to the removal of the fat. This assumption was similar to that obtained by Moses et al., for Lima bean (Phaseolus Lunatus).

Fat, a major component, which is also an avenue of production of nutritional and biologically active compounds such as fatty acids of the mono- and polyunsaturated class, tocopherols and phytosterols, reduced with germination time for both the flour and the isolate. Several researchers have reported the degradation of fat as a result of germination process. Comparable results were obtained for Soya bean, Mungbean, Sesame and three- genotypes of Cowpea on germination [37]. This reduction in oil content on malting, may be connected to its utilisation as a source of energy in malting process [38] energy for germination is obtained through the oxidation of fatty acids to carbon dioxide and water [39]; could also be as a result of enhanced lipolytic enzymes activities during germination [40]. The decrease in fat content is equally very good for shell life stability. The germinated flour and isolate will be able to last longer on the shelf than the ungerminated samples.

Ash content generally reduced with germination, only the $48 \mathrm{~h}$ protein isolate of DAS and the $6 \mathrm{~h}$ isolate of BS had values greater than the control. This reduction in ash content was parallel to observation in Soybean; Mung bean and Sesame [41]. The reduction in content of ash may be as a result of mineral loss in water during washing in order to minimise the acerbic smell produced over the period of sprouting. On the converse, Chinma et al, observed an increment in ash content for varieties of tigernut also observed weighty rise in the ash content after germination in each varieties of cowpea improved genotype (PL-1, PL-2 and PL-3) used by them, which they surmised as probably due to loss of carbohydrate. The reduction in ash content observed in this project may be as a result of the leaching of both the macro and micro elements as a result of soaking.

The indigestible plant material capable of lowering the level of blood cholesterol, preventing cancer, reducing the hazard of developing hypertension, diabetes and hypercholesterolemia is the crude fiber [42]. The crude fibre of germinated FFDAS, FFBS and DFDAS generally reduced with germination, except for $72 \mathrm{~h}$ for all of them and $24 \mathrm{~h}$ FFDAS. While DFBS had its crude fibre increasing with germination except that of $36 \mathrm{~h}$ which reduced. The experienced reduction is probably due to degradation of fibre into simple sugars brought about by endogenous enzymes. This is collaborated by other research work on chickpea, mungbean, kidney beans [43]. Enujiugha et al. [44] also observed a reduction in crude fibre with germination, with value going from $47.9 \%$ to $38.8 \%$, for African oil bean. Likewise, Ramadan [45] had a similar observation for soybean which was attributed to reduction in indigestible dietary fibre during germination.

On the contrary, Chinma et al., observed increase in crude fibre content with germination for the two tigernut varieties; Rumiyati et al., also observed increase for Australian sweet lupin; and Borijindakul and Phimolsiripol for Lablab. Rusydi et al., [46] during the study of germination effect on crude fibre for four legumes, observed, that the crude fibre of Kidney bean and Mung bean both decreased with germination, while that of soya bean and peanut increased with germination. Thus, it could be concluded that the effect of germination on crude fibre depended on the nature of the legume. Victor N. Enujiugha et al. in 2003, [47], observed decrease in fiber in soaked peanut, mung bean, wheat, and barley, but contrariwise increased in soaked soy bean and rice. This led to the conclusion that, fiber level is actually affected during the soaking period rather than at the germination proper.

The total carbohydrate quantity as Nitrogen free extractive was calculated by difference and was found to reduce with rise in germination time for the DAS flour and isolate, while the NFE of the BS variety of both flour and isolate increased with germination. The observed reduction was similar to the observation of D'souza for field beans, Devi et al. for three genotypes of cowpea. This decrease could be ascribed to the use of carbohydrate to give energy to the growing embryo for germination. The complex carbohydrate is fragmented to smaller sugar molecules such as glucose and fructose needed by the growing seed by the increased activity of $\alpha$-amylase at early stage of germination [48].

\section{Conclusion}

This research work shows that biochemical modification (Germination/Malting/ Sprouting) had an enormous impact on the nutritional composition, functional properties, mineral bioavailability, anti-nutrient content and amino assay of Solojo bean, thus, it could be used as protein supplement in infant, young children and geriatric foods.

Efforts should be increased to promote the cultivation, encourage the consumption and industrial application of this under-utilized legume by the Government, especially in the south-western region where it can survive the rain fall level. Large scale production of this legume which is gradually going into extinction should be encouraged in order to fight the menace of malnutrition in developing countries where animal protein price is exorbitant; This will ensure food security and also creation of jobs, because people can engage in different aspects of the production process and thereby reducing the rate of unemployment.

\section{References}

[1] Ali, N A., Ahmed, S H., Mohamed, E A., Ahmed, I. A. M and Babiker, E E. 2010. Changes in functional properties by transglutaminase cross linking as a function of $\mathrm{pH}$ of legumes protein isolate. Innovative Romanian Food Biotechnology. 7, $12-20$. 
[2] Salma H. Ahmed, Isam A. Mohamed Ahmed, Mohamed M. Eltayeb, Suha O. Ahmed, Elfadil. E. Babiker, 2011.

[3] Aiking, H. 2011. Future protein supply. Trends in Food Science and Technology, 22, 112-120.

[4] Jahreis G., Brese M., Leiterer M., Schafer U., Bohm V. 2016. Legume flours: Nutritionally important sources of protein and dietary fiber. Ernahrungs Umschau 63 (02): 36-42.

[5] Skylas, D. J., Molloy, M. P., Willows, R. D., Blanchard, C. L. and Quail, K. J. 2017. Characterisation of Protein Isolates Prepared from Processed Mungbean (Vigna radiata) Flours. Journal of Agricultural Science; Vol. 9, No. 12.

[6] Oreopoulou, V. and Tzia, C. 2007. Utilization of plant byproducts for the recovery of proteins, dietary fibers, antioxidants, and colorants. In Utilization of byproducts and treatment of waste in the food industry. Springer US. pp. 209232 .

[7] Sibt-e-Abbas, M., Butt, M. S., Sultan, M. T., Sharif, M. K., Ahmad, A. N. and Batool, R. 2015. Nutritional and functional properties of protein isolates extracted from defatted peanut flour, International Food Research Journal 22 (4): 1533-1537.

[8] Singhal, A., Can Karaca, A., Tyler, R. and Nickerson, M. 2016. Pulse Proteins: From Processing to Structure-Function Relationships.

[9] Klupšaitė, D. Juodeikienè, G. 2015. Legume: Composition, Protein Extraction and Functional Properties. A review. ISSN 1392 - 1231. Cheminè Technologija. Nutrition. 1 (66).

[10] Aletor, O. and Ojelabi, A. 2007. Comparative Evaluation of the Nutritive and Functional Attributes of Some Traditional Nigerian Snacks and Oil Seed Cakes. Parkistan Journal of Nutrition. 6 (1): 99-103.

[11] Mune, M. A. M., Minka, S. R. and Mbome. I. L. 2013. Chemical composition and nutritional evaluation of a cowpea protein concentrate Global Advanced Research. Journal of Food Science and Technology: 2 (3) pp. 035-043.

[12] Mudryj, A. N., Yu, N. and Aukema, H. M. 2014. Nutritional and health benefits of pulses. Applied Physiology Nutrition and Metabolism. 39: 1197-1204. DOI: 10.1139/apnm-20130557 .

[13] Mohammad Aghajanpour, Mohamad Reza Nazer, Zia Obeidavi, Mohsen Akbari, Parya Ezati, Nasroallah Moradi Kor (2017), "Functional foods and their role in cancer prevention and health promotion: a comprehensive review", Am J Cancer Res.; 7 (4): 740-769.

[14] Shimelis, E. A., and Rakshit, S. K. 2007. Effect of processing on antinutrients and in vitro protein digestibility of kidney bean (Phaseolus vulgaris L.) varieties grown in East Africa. Food Chemistry, 103 (1), 161-172. doi: 10.1016/j.foodchem.2006.08.005.

[15] Mirmoghtadaie, L. Shojaee, S., Seyede, A. and Hosseini, M. 2016. Recent approaches in physical modification of protein functionality. Food Chemistry, 199: 619-627.

[16] Marco-moles, R., Hernando, I., Perez- Munuera, I. 2012. Influence of high-pressure homogenization (HPH) on the structural stability of an egg/dairy emulsion. Journal of Food Engineering. 109 (4) 652-658.
[17] D'Astolfo, D. S., Pagliero, R. J., Pras, A., Karthaus, W. R., Clevers, H., Prasad, V. and Geijsen, N. 2015. Efficient Intracellular Delivery of Native Proteins. Cell, 161 (3), 674690. doi: 10.1016/j.cell.2015.03.028.

[18] Alashi, A., Blanchard, C. Mailer, R. and Agboola S. 2011. Improving the emulsifying properties of canola meal protein isolate by enzymatic modification 17th Australian Research Assembly on Brassicas (ARAB) Wagga Wagga.

[19] Lawal O. S. and Adebowale K. O. 2006. The acylated protein derivatives of Canavalis ensiformis (Jack bean). A study of functional characteristics. Food Technology 39: 918-929.

[20] MacDonald, J. I., Munch, H. K., Moore, T., and Francis, M. B. 2015. One-step site-specific modification of native proteins with 2-pyridinecarboxyaldehydes. Nature Chemical Biology, 11 (5), 326-331.

[21] Salma, H. A., Nahid, A. A., ElShazali, A. M., Isam, A. M. A. and Elfadil, E. B. 2010. Changes in the functional properties as a function of $\mathrm{NaCl}$ concentration of legumes protein isolate by transglutaminase cross linking. International Food Research Journal. 17: 817-824.

[22] Barac, M., Cabrilo, S., Pesic, M., Pavlicevic, M., Macej, O. and Ristic, N. 2011. Functional Properties of Pea (Pisum sativum, L.) Protein Isolates Modified with Chyosin. International Journal of Molecular sciences (12) 8372-8387.

[23] Zang, X., Yue, C., Wang, Y., Shao, M., and Yu, G. 2018. Effect of limited enzymatic hydrolysis on the structure and emulsifying properties of rice bran protein. Journal of Cereal Science. doi: 10.1016/j.jcs.2018.09.001.

[24] Wouters, A. G. B., Rombouts, I., Fierens, E., Brijs, K. and Delcour, J. A. 2016. Relevance of the Functional Properties of Enzymatic Plant Protein Hydrolysates in Food Systems. Comprehensive Reviews in Food Science and Food Safety, 15 (4) 786-800.

[25] Sosulski FW, Kasirye-Alemu EN, Sumner AK (1987) Microscopic, nutritional and functional properties of cowpea flours and protein concentrates during storage. J Food Sci 52: 700-706.

[26] Gaspar, A. L. C., and de Góes-Favoni, S. P. 2015. Action of microbial transglutaminase (MTGase) in the modification of food proteins: A Review. Food Chemistry, 171, 315-322.

[27] Nahid, A. A., Salma H. A., ElShazali, A. M. and Elfadil, E. B. 2010. Transglutaminase cross-link of legumes protein isolate: changes in functional properties as a function of $\mathrm{pH}$. International Food Research Journal 17: 1011-1018 (2010).

[28] Abdalla MH, Elkhalifa AO, Eltinay AH, (2001)," Functional Properties of Cowpea (Vigna Ungiculata L. Walp), and Lupin”. Journal of Nutrition \& Food Sciences. 3: 6.

[29] Chinma C. E, Emelife I. G, and Alemede I. C (2008)," Physicochemical and Functional Properties of Some Nigerian Cowpea Varieties". Pakistan Journal of Nutrition 7 (1) DOI:10.3923/pjn.2008.186.190.

[30] Rumiyati Rumiyati (2012), "Effect of Germination on the Nutritional and Protein Profile of Australian Sweet Lupin (Lupinus angustifolius L.)", Food and Nutrition Sciences 03 (05): 621-626.

[31] Myrene D'souza (2013)," Effects of traditional processing methods on nutritional quality of Field bean". Advances in Bioresearch 4 (3): 29. 
[32] Kavitha Sampathand and Ramanathan Parimalavalli (2014)," Effect of processing methods on proximate composition of cereal and legume flours". Journal of Human Nutrition \& Food Science. 2 (4): 1051.

[33] Archana Devi; Manoranjan Kalia; Gupta, V. K.; Katoch, B. S. 1997. Effect of feeding different levels of khesari (Lathyrus sativus) and vetch (Vicia sativa) proteins on the performance of starter chicks. Indian J. Nutr. Diet., 34 (2): 49-58.

[34] Ge Zhang, Zhicun Xu, Yuanyuan Gao, Xianxiao Huang, Yanping Zou and Tiankui Yang (2015)," Effects of Germination on the Nutritional Properties, Phenolic Profiles, and Antioxidant Activities of Buckwheat". A Publication of the Institute of Food Technologists. Volume 80, Issue 5. Pages H1111-H1119.

[35] T. A. El-Adawy, E. H. Rahma, A. A. El-Bedawey \& A. E. ElBeltagy (2003),"Nutritional potential and functional properties of germinated mung bean, pea and lentil seeds". Plant Foods for Human Nutrition volume 58, pages 1-13.

[36] Dipika Murugkar and Krishna Jha (2013)," Effect of drying on nutritional and functional quality and electrophoretic pattern of soyflour from sprouted soybean (Glycine max)" Journal of Food Science and Technology -Mysore- 47 (5): $482-7$.

[37] Agugo U. A., Asinobi C. O., and Afam-Anene C. \{2016)," Investigating the nutritional, sensory and storage qualities of substituted mungbean-garri diets". Journal of Food Technology and Preservation (2020) Volume 4, Issue 4.

[38] Morteza Oghbaei, Jamuna Prakash and Fatih Yildiz, (2016)," Effect of primary processing of cereals and legumes on its nutritional quality: A comprehensive review". Cogent Food And Agriculture 2 (1): 1-29.

[39] Masood Sadiq Butt and Rizwana Batool, (2010), "Nutritional and Functional Properties of Some Promising Legumes Protein Isolates". Pakistan Journal of Nutrition 9 (4).

[40] Reihaneh Ahmadzadeh Ghavidel and amuna Prakash, (2007)," The impact of germination and dehulling on nutrients antinutrients in vitro iron and calcium bioavailability and in vitro starch and protein digestibility of some legume seed". LWT- Food Science and Technology 40 (7): 1292-1299.

[41] Chiemela Enyinnaya, Chinma, Olufemi Adewuyi and Joseph ONEH Abu (2009)," Effect of germination on the chemical and pasting properties of flour from brown and yellow varieties of tigernut (Cyperus esculentus)". Food Research International 42 (8): 1004-1009.

[42] Dejene Dida. 2010. Study on the Effect of Traditional Processing on Proximate Composition and Bioavailability of Minerals in Chickpea (Cicer arietinum) grown in Ethiopia. MSc Thesis, Addis Ababa University, Addis Ababa. 80pp.

[43] Ragab DDM, Babiker EE, Eltinay AH (2004) Fractionation, solubility and functional properties of cowpea (Vigna unguiculata) proteins as affected by $\mathrm{pH}$ and/or salt concentration. J Food Chem 84: 207-212.

[44] Smith G. Nkhata, Emmanuel Ayua, Elijah H. Kamau, and Jean-Bosco Shingiro, (2018), "Fermentation and germination improve nutritional value of cereals and legumes through activation of endogenous enzymes". Food Sci Nutr. 6 (8): 2446-2458.

[45] Beruk Berhanu. 2013. Formulation of Nutritionally Improved Complementary Food: The case of Shebedino Woreda, Southern Ethiopia. MSc Thesis, Hawassa University, Hawassa.110pp.

[46] M. R. Megat Rusydi, C. W. Noraliza, Azrina Azlan, Zulkhairi Amom (2011), "Nutritional changes in germinated legumes and rice varieties", International Food Research Journal 18 (2)

[47] Victor Ndigwe Enujiugha, Adebanjo Badejo, Matthew Olusola Oluwamukomi and Samuel O Iyiola (2003)," Effect of germination on the functional properties of African oil bean (Penthaclethra macrophylla Benth) seed flour". Food, Agriculture \& Environment Vol. 1 (3\&4): 72-75. 2003.

[48] B. M. Warle, Charanjit Singh Riar and Sandeep S. Gaikwad and V. A. Mane (2015), "Effect of Germination on Nutritional Quality of Soybean (Glycine Max)". International Journal of Current Research 07 (5): 16029-16034. 